\title{
An Empirical Investigation into the Effect of Financial Sector Development on Consumption and Inflation in Nigeria: 1986-2012
}

\author{
M. N. G. Omofa \\ Department of Economics, Kogi State University, Anyigba, Nigeria \\ Email: omofamng@gmail.com
}

How to cite this paper: Omofa, M.N.G. (2017) An Empirical Investigation into the Effect of Financial Sector Development on Consumption and Inflation in Nigeria: 1986-2012. Open Journal of Business and Management, 5, 11-21.

http://dx.doi.org/10.4236/ojbm.2017.51002

Received: May 3, 2016

Accepted: November 28, 2016

Published: December 1, 2016

Copyright $\odot 2017$ by author and Scientific Research Publishing Inc. This work is licensed under the Creative Commons Attribution International License (CC BY 4.0).

http://creativecommons.org/licenses/by/4.0/

\begin{abstract}
Private consumption expenditure is one of the largest components of aggregate expenditure in Nigeria. It constitutes about $72 \%$ of GDP over the period understudy. It is therefore an important aspect of the macro-economy of any nation. In the same vein inflation has been a persistent evil affecting the economy of Nigeria. So they are both required to have a deep understanding of how macro-economy functions. The determinants of these two aggregates can therefore not be divorced from the activities in the financial sector. Hinging on the Keynesian absolute income consumption hypothesis, the paper used 3 SLS to estimate the two macroeconomic equations. The results showed that money supply, market capitalization and exchange rate had positive impact on personal consumption expenditure. However, it is only market capitalization that is not statistically significant. All the financial variables used-money supply, interest rate and exchange rate had positive relationship with the general price level. However it was only exchange rate that was not statistically significant. The paper concluded that shocks in the financial sector explained the variations in personal consumption and inflation. It was therefore recommended that interest rate and exchange rate should not be absolutely left to the dictate of the market forces. Government should intervene occasionally as the case may demand. Conducive environment that will make activities in the capital market should be encouraged.
\end{abstract}

\section{Keywords}

Personal Consumption Expenditure, Inflation, General Price Level, Money Supply, Rate of Interest, Market Capitalization, Exchange Rate, Simulation, Market Forces, Financial Sector Development

\section{Introduction}

The Nigerian economy has been characterized by low productivity of factor inputs, reliance on mono-product base, low and falling capacity utilization of the manufacturing sector, high volatility in foreign exchange earnings and its depreciation which raises 
input cost for the manufacturing sector, high cost of borrowing, and high inflation while stock prices were falling culminating in losses for the investors. For example, the lending rate which was $10 \%$ in 1986 rose to $12 \%$ in 2012 . This increased the cost of borrowing and stifled investment. The consumer price index which stood at $10.42 \%$ in 1992 rose to $84.90 \%$ in 2001 and finally to $141.1 \%$ in 2012 . This translates to a rise in the index to about 74\% between 1992 and 2001 and about $60 \%$ between 2001 and 2012 . Other features of the Nigerian economy include weak infrastructural base, high unemployment rate which kept on rising over the years except in 2012 when it fell to $17.17 \%$ from $23.4 \%$ in 2011 , phenomenal growth in money supply fuelled by high fiscal deficits, and balance of payment deficits. These have been the case in spite of the various reforms in the financial sector since 1986.

In 1987, the Federal Government of Nigeria commenced an extensive reform of the financial system as part of a Structural Adjustment Programme (SAP). The reforms in the capital, money and foreign exchange markets involved liberalizing interest and exchange rates, promoting a market-based system of credit allocation, flexible exchange rate system for naira, enhancing competition and efficiency in the financial system as well as strengthening the regulatory and supervisory framework of the financial system. However recent and current development in the economy has made it not clear if the reforms have achieved the desired results.

With SAP in 1986 and the consequent expansionary fiscal and monetary policies of the federal government, money supply jumped from $1.2 \%$ in 1986 to $60.4 \%$ in 1992 before declining to $18.4 \%$ in 1998 . By year 2000 it increased by $62.2 \%$ before declining to 29.5\% in 2003 and 6.3\% in 2007 (CBN Annual Statement, 2009) [1]. In 2009, money supply figure stood at N107 billion but rose to N154.8 billion in 2012 (CBN, 2012) [2]. This represents about $44.7 \%$ increase over the period. The overall increase in money supply usually, leads to a situation of too much money chasing too few goods making prices of goods and services equally increase. The prime lending rate equally rose sharply from $9.25 \%$ in 1985 to $36.09 \%$ in 1993 before declining to $18.4 \%$ in 1998 and subsequently to $16.94 \%$ in 2007 (CBN Annual Statement, 2009) [1]. It increased in 2009 to $18.9 \%$ before marginally reducing to $16.79 \%$ in 2012 (CBN, 2012) [2]. The increase in the prime lending rate resulted in high costs of borrowing to the real sector thereby further reinforcing the high cost of production and the unit price of goods and services.

Consequent upon the above, inflation rate climbed to $57.25 \%$ in 1993 before it fell to $8.5 \%$ in 1997 . By 2005 it stood at $17.9 \%$ while it dropped to a single digit of $5.4 \%$ in 2007. It was $12.4 \%$ in 2009 exceeding both the national and West African Monetary Zone single-digit inflation rate target (CBN, 2009) [1]. In general, however, inflation trend in Nigeria has been on a decline since 2000. It has been on a single digit since the late part of the first decade of the century till date.

Consumption is also one of the measures of performance of the macro-economy of a country. It tells about the share of the total output of the economy that goes to households. Therefore consumption affects the welfare of the citizenry. Personal consumption in Nigeria has increased over the years. It increased from N51, 537M in 1986 to $\mathrm{N} 1,387,445 \mathrm{M}$ in 1995 . The figure was put at N11, 07505M in 2005 before it finally increased to N17, 539, 049M in 2010. Over the entire period, personal consumption kept on rising. The rise in personal consumption profile in Nigeria was due to the increase 
in salaries and wages of workers. Particularly, the minimum wage and the monetization of fringe benefits policy implemented by both Abdulsalam and Obasanjo made the disposable income of workers to increase. Also, the high cost of borrowing and the non-competitiveness of the domestic product at the international market coupled with the import consumption orientation of the citizens made lending to firms by commercial banks more risky. This made the commercial banks to divert attention from lending to firms to that of individual household. The credits to the household were used for private consumption such as cars, electronics and laptops/personal computers which had to be imported.

It therefore becomes imperative to empirically investigate the effect of financial sector development on inflation and consumption in Nigeria between 1986 and 2012.

The paper is divided into five sections. Section one generally introduced the topic while section two discusses literature and theoretical nexus. Section three contains methodology while section four discusses empirical results. Section five summarizes, concludes and gives recommendations.

\section{Literature and Theoretical Nexus}

Keynes was the first to make consumption a central part of macroeconomic theory. Keynes based his analysis on fundamental psychological rule of modern community that when real income increased, consumption will not increase by an equal amount. This is to enable a greater amount to be saved, unless a large and un-usual change is occurring at the same time, then will it not be so (Keynes, 1936; 97) [3].

The major assumptions underlying Keynes absolute income hypothesis as identified by Aigbokhian (1996) [4] are; current consumption must be a positive stable function of current income; MPC is less in the short run than in the long run making consumption increase by a far lesser amount than the increase in disposable income; in the long run, a smaller proportion of income will be consumed as income increases; at low level of disposable income, consumption will exceed income; and finally, changes in the stock of the wealth will directly affect households level of consumption .

However, Kuznet's study (1942) [5], casted doubts on the hypothesized long run stability of the aggregate consumption. He found out that long run aggregate consumption was proportional to disposable income and therefore the long run MPC remained constant and was equal to the APC. This led to the development of alternative hypotheses which are the Duesenberry relative income hypothesis (1948) [6], the Modgliani and Brumbergh life cycle hypothesis (1954) [7] and the Friedman Permanent income hypothesis (1956) [8].

The life cycle and the permanent income hypotheses were founded on intertemporal decisions on the view that when individuals are planning current consumption, they consider not only current income but also future income and future consumption. In other words, they do not deny the influence of current consumption even though their model is neo-classical.

This work therefore adopts the framework of Keyenesian's foundations of the consumption function. However by extension it included other financial sector determinants of consumption demand. These would include prices, expectations of inflation, wealth taxes e.t.c. (see Baye, 2006) [9]. 


\section{Model Specification}

Given the developing nature of the Nigerian economy disposable income (DY) plays a significant role in private consumption because the marginal propensity to consume (MPC) in LDC is high. Interest rate (ROT) which affects domestic credit level which in turn influences private consumption positively hence output is of interest. Also, the rate of interest can become a liquidity constraint because consumers may not be able to borrow easily, which means that during recessions they cannot obtain the necessary funds to maintain their consumption. The real rate of interest can also become a factor in consumption because it affects the price of future consumption relative to present consumption. In fact, the real rate of interest is the relative price between present consumption and future consumption. It thus directly affects the choice of whether to consume more today or more tomorrow. If the real rate of interest is positive as it is generally, people face an incentive to defer spending (consumption) unless they are too impatient. This impatience is called the rate of time preference. If the real rate of interest is higher than the time preference, then people will tend to shift consumption a bit toward next year (Hall and Taylor, 1991) [10]. A Naira saved today will buy more than a naira of goods tomorrow. If the real rate of interest is high, today's consumption will tend to be low. This factor therefore makes consumption to be negatively related to rate of interest.

Money supply is included in this block as financial variable. This is because as money balances grow more rapidly as a result of excess money supply in the economy in relation to income people will attempt to spend the excess. On the other hand if money grows too slowly in relation to income, people would build up their cash balances by reducing spending.

Exchange rate inclusion as a financial variable is predicated upon the fact that most of the Nigerians' demands are import oriented. Scarcity of foreign exchange and the devaluation of local currency make import dearer thus acting as a constraint to the amount of such goods and services that consumer would buy within a given income. Other non-financial variables include disposable income and the general price level.

Therefore the Personal consumption expenditures equation was specified in a linear form as thus;

$$
\mathrm{PCE}=C_{1}+C_{2} \mathrm{ROT}+C_{3} \mathrm{MS}+C_{4} \mathrm{EXR}+C_{5} \mathrm{DY}+C_{6} \mathrm{GPL}+U_{t}
$$

where PCE $=$ Personal consumption Expenditure

$$
\begin{aligned}
& \text { ROT = Rate of Interest } \\
& \text { MS = Money Supply } \\
& \text { EXR = Exchange Rate } \\
& \text { DY = Disposable Income } \\
& \text { GPL = General Price Level proxied by price index. }
\end{aligned}
$$

The price equation is a behavioural equation in which inflation in Nigeria is believed to be a monetary phenomenon (Omofa, 2006) [11]. According to the quantitist's theory of money, an increase in money supply that will lead to too much money in circulation competing over too few goods will result the general increase in price level. This is based on the assumption that the national output cannot be expanded beyond the level it has already attained. Also, exchange rate depreciation would make foreign goods 
dearer as it requires more naira to import them. Given that Nigerian economy is a dependent economy where both consumption goods and capital goods are imported, the country cannot be exempted from the variant of imported type of inflation. Interest rate variable is included in the equation as a proxy for the opportunity costs of holding money. When the real cash balance holding of the public increases beyond its desired level, there will be portfolio assets holding adjustment of the public. So if the public decide to hold the idle cash balance in money, he would have to forego the interest on the yielding asset. Thus interest rate becomes a proxy for the opportunity costs of holding money. Inflation therefore is negatively related to interest rate. Finally, the price mark up theory suggests that prices are inflexible downward due to rigidities in the market. Thus current prices are reflection of the price level lagged. Also included in the equation is the fiscal deficit of government which helps in fuelling the money supply of the economy.

We specify the price equation in Equation (2) thus;

$$
\mathrm{GPL}_{t}=C_{7}+C_{8} \mathrm{MS}+C_{9} \mathrm{ROT}+C_{10} \mathrm{EXR}+C_{11} \mathrm{GDP}+C_{12} \mathrm{PFR}+C_{13} \mathrm{FIB}+U_{t}
$$

where

$$
\begin{aligned}
& \text { GPL = General Price Level } \\
& \text { MS = Money Supply } \\
& \text { ROT = Rate of Interest } \\
& \text { EXR = Exchange Rate } \\
& \text { GDP = Gross Domestic Product } \\
& \text { PFR = Prices of Foreign Products } \\
& \text { FIB = Fiscal Balance. }
\end{aligned}
$$

\begin{tabular}{|c|c|c|c|c|c|}
\hline \multicolumn{6}{|c|}{$\mathrm{PCE}=1727288-60901.7 \mathrm{ROT}+0.93 \mathrm{MS}+4434.75 \mathrm{EXR}-14.1 \mathrm{DY}_{\mathrm{t}}+$} \\
\hline \multicolumn{6}{|l|}{$\begin{array}{c}\text { 4103.13GPL } . . \\
(0.73)\end{array}$} \\
\hline \multicolumn{6}{|l|}{$\mathrm{R}^{2}=0.89$} \\
\hline \multicolumn{6}{|l|}{$\check{\mathrm{R}}^{2}=0.87$} \\
\hline \multicolumn{6}{|c|}{$\mathrm{GPL}=-115.41+0.000004 \mathrm{MS}-1.49 \mathrm{ROT}+0.06 \mathrm{EXR}+0.00061 \mathrm{GDP}+0.24 \mathrm{PFR}-$} \\
\hline $\operatorname{Pr} \quad(0.0000)$ & $(0.0003)$ & $(0.0004)$ & $(0.45)$ & $(0.0000)$ & $(0.11)$ \\
\hline \multicolumn{6}{|c|}{ 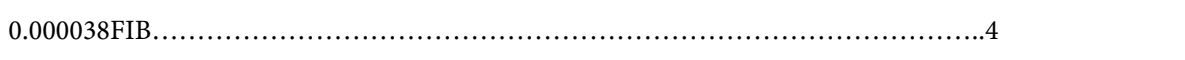 } \\
\hline \multicolumn{6}{|l|}{$\mathrm{R}^{2}=0.98$} \\
\hline$\check{\mathrm{R}}^{2}=0.97$ & & & & & \\
\hline
\end{tabular}

\section{Empirical Results}

The regression results of the aggregate consumption represented by Personal Consumption Expenditure (PCE), Equation (3) and that for inflation represented by GPL, Equation (4) are presented in Table 1 below followed by their discussion.

Table 1. Empirical results for personal consumption expenditure and inflation. 
In addition to the functional determinants of personal consumption by Keynes, financial sector variables such as money supply (MS), rate of interest (ROT) and exchange rate (EXR) were used in the regression analysis. The rate of interest (ROT) was correctly signed. Theory, puts it that if ROT is low, it decreases the cost of borrowing to finance personal consumption. Also if interest rate is low, people will hold more money. The excess money held above the desired demand for money will translate to more personal transaction and consumption. The coefficient is high but it is not significant. This may not be unconnected with the fact that interest rate influence on consumption is not a direct one. Exchange rate (EXR) was correctly signed. An appreciation of exchange rate implied an increase in the value of naira. This increased the value of total foreign goods and services that people purchased. The coefficient was high and it was significant. Money supply (MS) was correctly signed as increase in the money supply would increase the portfolio holding of consumers and this excess holding would therefore be spent on consumption. The coefficient of money MS was low but highly significant. Expectedly, for other non-financial sector variables, the general price level (GPL) was negatively signed. This conforms to the theoretical argument that people buy more when prices are low. The coefficient of the present price level is high but not significant in determining the present personal consumption. The coefficient of disposable income was high and wrongly signed. This is because if disposable income is low, people tend to consume a significant proportion of their income but at high level of disposable income, people tend to save a large proportion of it. Its probability is 0.48 . This shows that disposable income is not statistically significant at $5 \%$. The $\mathrm{R}^{2}$ and $\check{\mathrm{R}}^{2}$ show that $89 \%$ and $87 \%$ of the variability in the dependent variables are explained by the developments in the financial sector respectively. The fit is therefore high.

The equation for the general price level (GPL) price contained in Table 1, made use of Money Supply (MS), exchange rate (EXR) and rate of interest (ROT) as the financial variables of concern.

From Table 1, the results showed that all the variables are correctly signed except ROT. This is explained by the fact that expectation of future rise in prices in Nigeria is being adjudged correctly by the populace. The coefficients of all the variables are low except interest rate but the probability showed that they all have significant impact on price equation (GPL) with the exception of EXR and PFR. The reason for the low significance of foreign prices (PFR) was based on the type of the data used. The research work made use of USA consumer price index on the bases that America is one of the major trading partners of Nigeria. However, China is gradually taking over from America as her goods becomes relatively cheaper compare with that of America making Nigerian consumption pattern to shift towards importation of goods from China. Hence the full effect of the imported type of inflation could not be felt. The overall fit is high at $98 \%$ suggesting that about $98 \%$ variation in the general price level is explained by the variation in the independent variables.

\section{Simulation Results}

In the money market, a decrease in money supply by $10 \%$ makes PCE to increase by $1.62 \%$ while GPL decrease by $2.98 \%$. An increase in money supply by $10 \%$ makes PCE 
decrease merely by $0.42 \%$ while GPL decreases by $4.6 \%$. These imply that a shock introduced by money supply in the money market affects GPL more than the PCE.A decrease in ROT by $10 \%$ merely increase PCE by $0.15 \%$ while GPL decrease also merely by $0.47 \%$. An increase in ROT by $10 \%$ merely makes PCE to decrease by $0.15 \%$ and GPL increase by $0.48 \%$. These imply that a shock via ROT may not have much impact on both PCE and GPL. Thus, they both respond to the stimulus of Money supply shock more than that of ROT.

In the capital market, a decrease in MCAP by $10 \%$ was introduced. This made PCE to decrease by $1.66 \%$ and GPL also reduced by $8.02 \%$. With an increase in MCAP by $10 \%$, PCE increased by $1.98 \%$ while GPL also increased by $8.71 \%$. These imply that the capital market shock affects both PCE and GPL. However, it has more/serious effect on GPL than on PCE.

In the foreign exchange market, a 10\% decrease in EXR makes PCE to increase by $0.11 \%$ while GPL reduced by $4.88 \%$. Also, a $10 \%$ increase in EXR will make PCE to reduce by $0.15 \%$ and also increase GPL by $4.88 \%$. These imply that foreign exchange market shock affects both PCE and GPL but affects the GPL more than PCE. This portrays that the Nigerian economy is bedeviled with a variation of imported inflation as the cost of imported inputs for the domestically produced goods rise from Naira depreciation. Also the consumption pattern of Nigerians is tailored towards imported goods.

The policy implication of these is that tight monetary control and stimulation of the capital market are needed to stimulate PCE and make prices attractive to producers to produce more. It also requires policies that will make Naira appreciate against the Dollar at the foreign exchange market to increase PCE and reduce GPL.

\section{Summary, Conclusion and Recommendations}

This work analyzed the distinct impact of each of the three financial markets (money, capital and foreign exchange markets) on consumption and inflation in Nigeria. The major findings of the work showed that:

1) MS and EXR had positive impact on PCE over the entire period under study. Although MCAP also had positive impact on PCE but it was not statistically significant.

2) All the financial variables used-MS, ROT and EXR, had positive relationship with GPL. They were also statistically significant with the exception of EXR.

3) The shocks in the financial sector also cause shocks for both personal consumption (PCE) and inflation (GPL). However it causes more serious concern for inflation (GPL) than personal consumption (PCE).

The work therefore concludes that development in the financial sector had serious impact on the macroeconomic objective of price stability and consumption expenditure of households.

From the study, it therefore becomes imperative to give the following recommendations.

The CBN contractionary monetary policy should be pursued to tame inflation thereby encouraging personal consumption.

The determination of interest rate should not be left to be determined exclusively by the forces of demand and supply. Occasionally government should intervene in this 
market based on the merit of the intervention or as deemed fit. This is because a rise in interest rate will be tantamount to increased cost of production which raises the general price level. A rise in interest rate will also stifle personal consumption as the cost of borrowing to finance consumption will also be high. It should also not be forgotten that interest rate could also be a proxy for expectation of inflation which has serious implications for the economy.

In addition, environment that will encourage activities in the capital market thereby creating bubbles without bursting should be pursued by the government as this would help in making prices become attractive for investors to invest more and producers to produce more.

Finally, like the interest rate, exchange rate should not be left to the absolute dictate of the forces of the market. Occasionally government should intervene to stem the continuous decline in the value of Naira against the major international currency like Dollar.

\section{References}

[1] CBN (2009) Central Bank of Nigeria Abstract and Annual Statement. CBN, Abuja.

[2] CBN (2012) Central Bank of Nigeria Statistical Bulletin. CBN, Abuja.

[3] Keynes, J.M. (1936) General Theory of Employment, Interest and Money. Macmillan, London.

[4] Ikhide, S.I. and Alawode, A.A. (2001) Financial Sector Reform, Macroeconomic Instability and the Order of Economic Liberalization: The Evidence from Nigeria. AERC Research Paper 112, Nairobi, Kenya.

[5] Kuznets, S. (1946) National Product since 1869. Epstein, L. and Zenks, E., Assisted, National Bureau of Economic Research, New York.

[6] Duesenberry, J.S. (1949) Income-Consumption Relations and Their Implications. In: Metzler, L., et al., Income, Employment and Public Policy, W.W. Norton \& Company, Inc., New York.

[7] Modgliani, F. and Brumberg, R. (1954) Utility Analysis and the Consumption Function; An Interpretation of Cross-Section Data. In: Kurihara, K.K., Ed., Post-Keynesian Economics, George Allen \& Unwin, London.

[8] Friedman, M. (1957) Theory of the Consumption Function. Princeton University Press, Princeton.

[9] Baye, M.R. and Jansen, D.W. (2006) Money, Banking, and Financial Markets: An Economics Approach. AITBS Publishers, India, 525.

[10] Hall, R.E. and Taylor, J.B. (1991) Macroeconomics; Theory, Performance and Policy. 3rd Edition, W.W. Norton and Company, New York.

[11] Omofa, M.N.G. (2006) Money Supply and Its Effect on the Nigerian Inflationary Process: Empirical Evidence from 1985 to 2000. Journal of Social Research, 1. 
Appendix

Tracking of Actual and Simulated Values

Tracking of Simulated Values of Money Supply

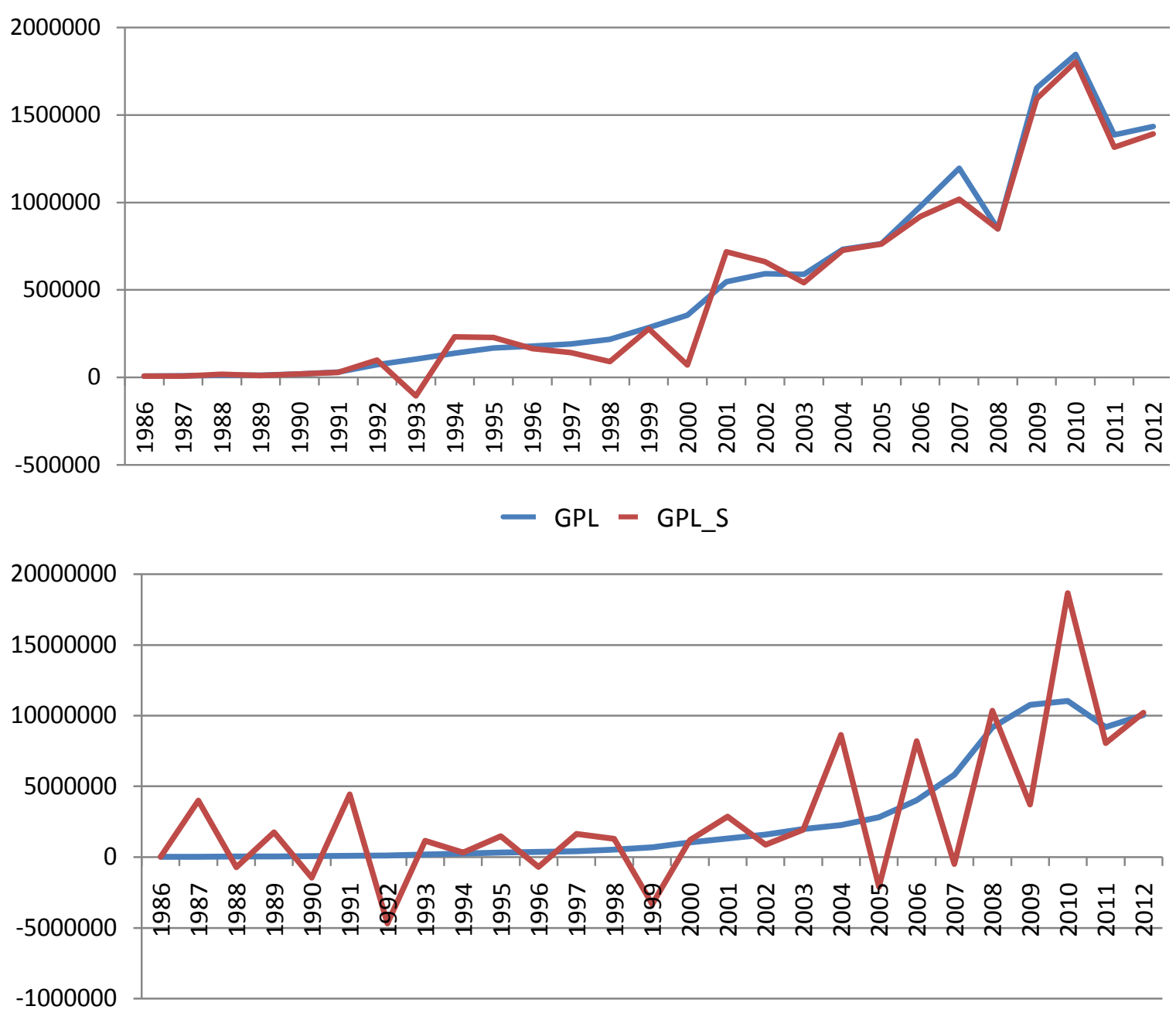$$
\longrightarrow \text { MS PCE_S }
$$

Tracking of Simulated Value of ROT

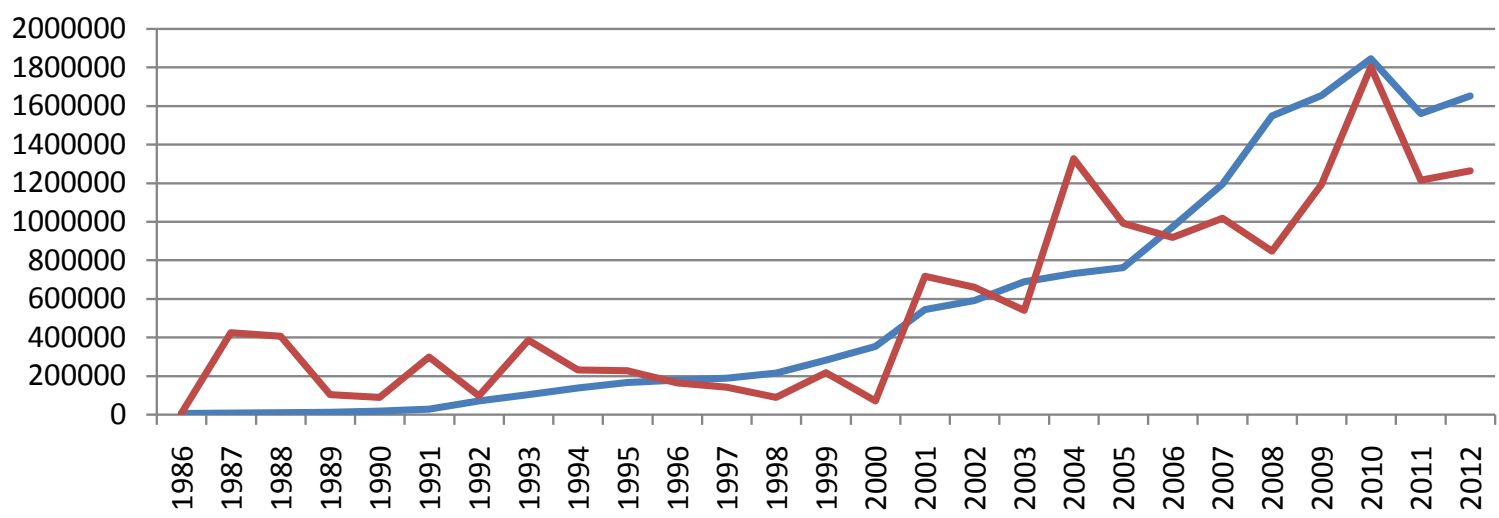

$-\mathrm{GPL} \longrightarrow \mathrm{GPL}$ 0 

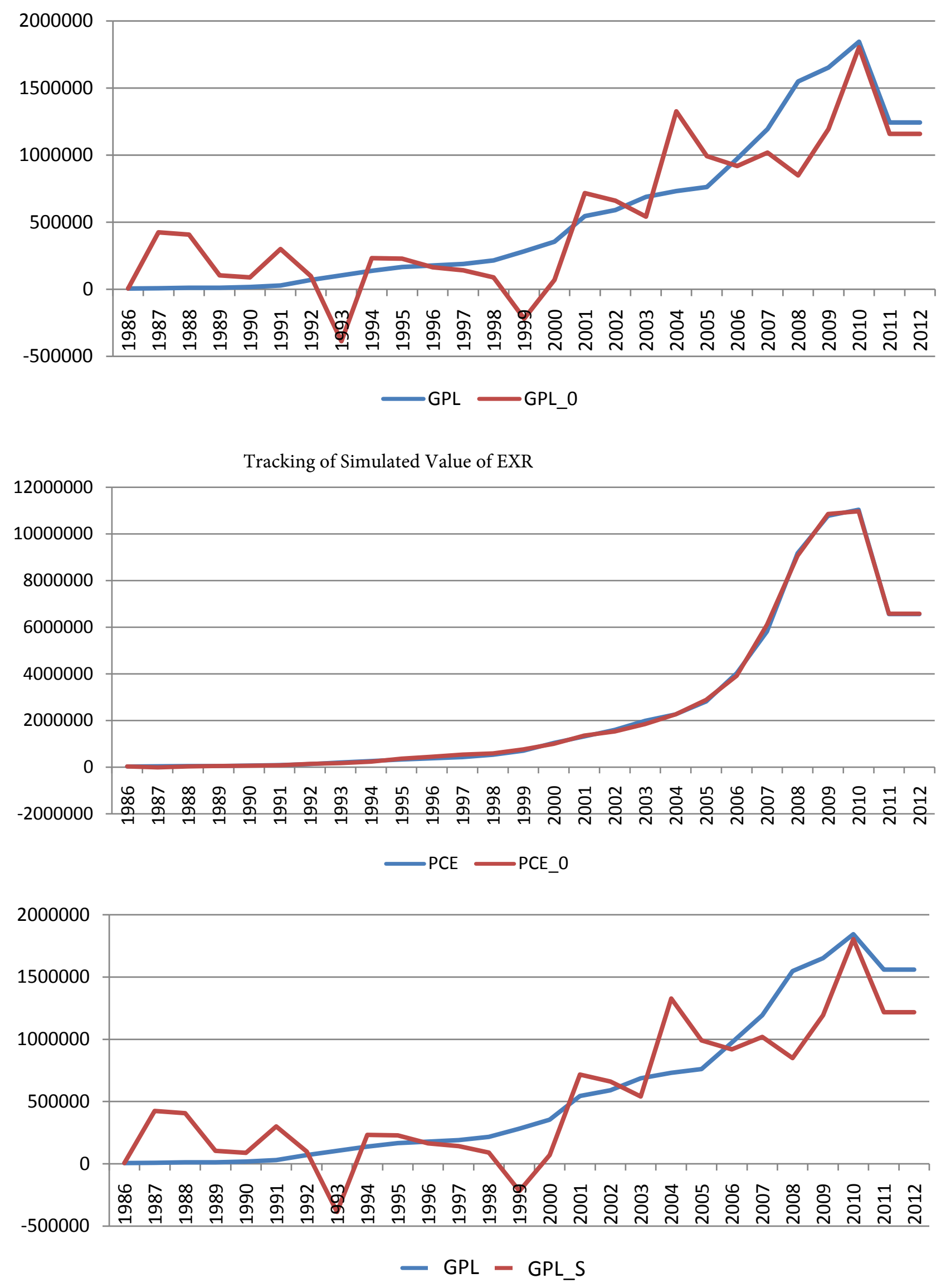
Tracking of Simulated Value of MCAP

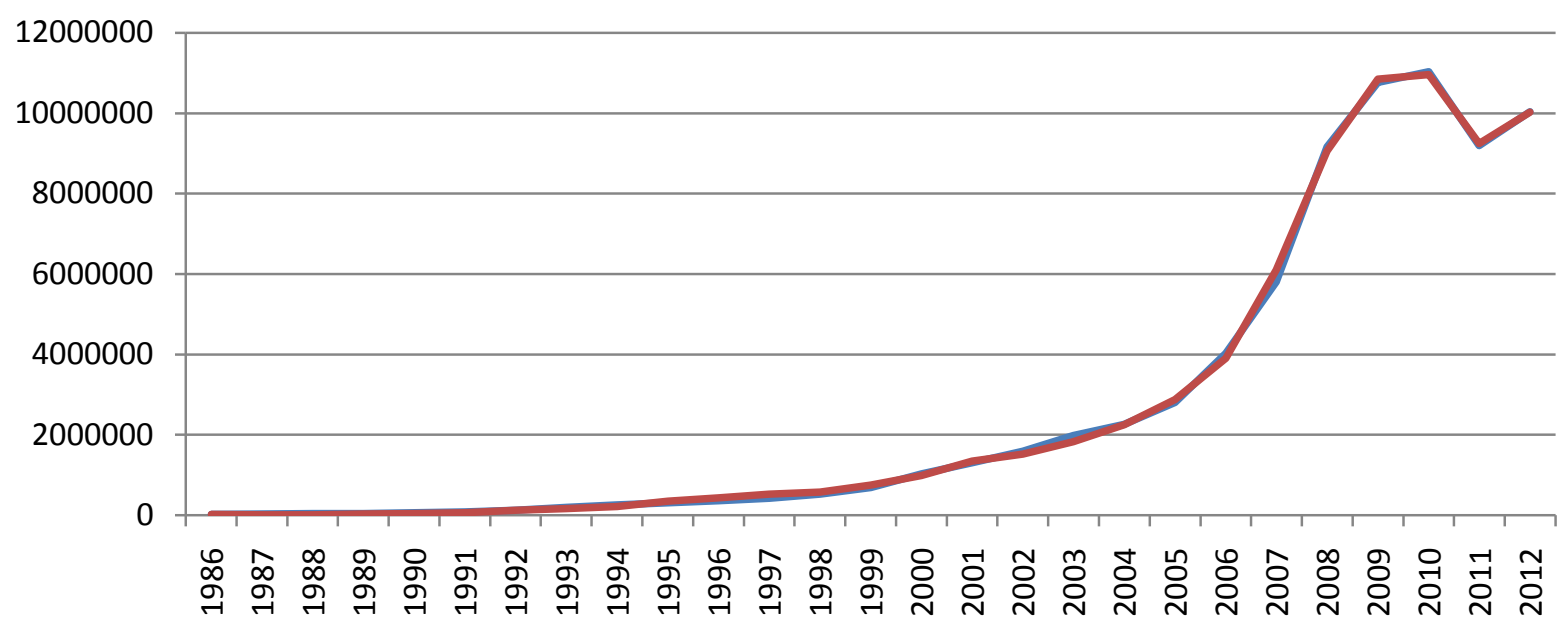

-PCE —PCE_0

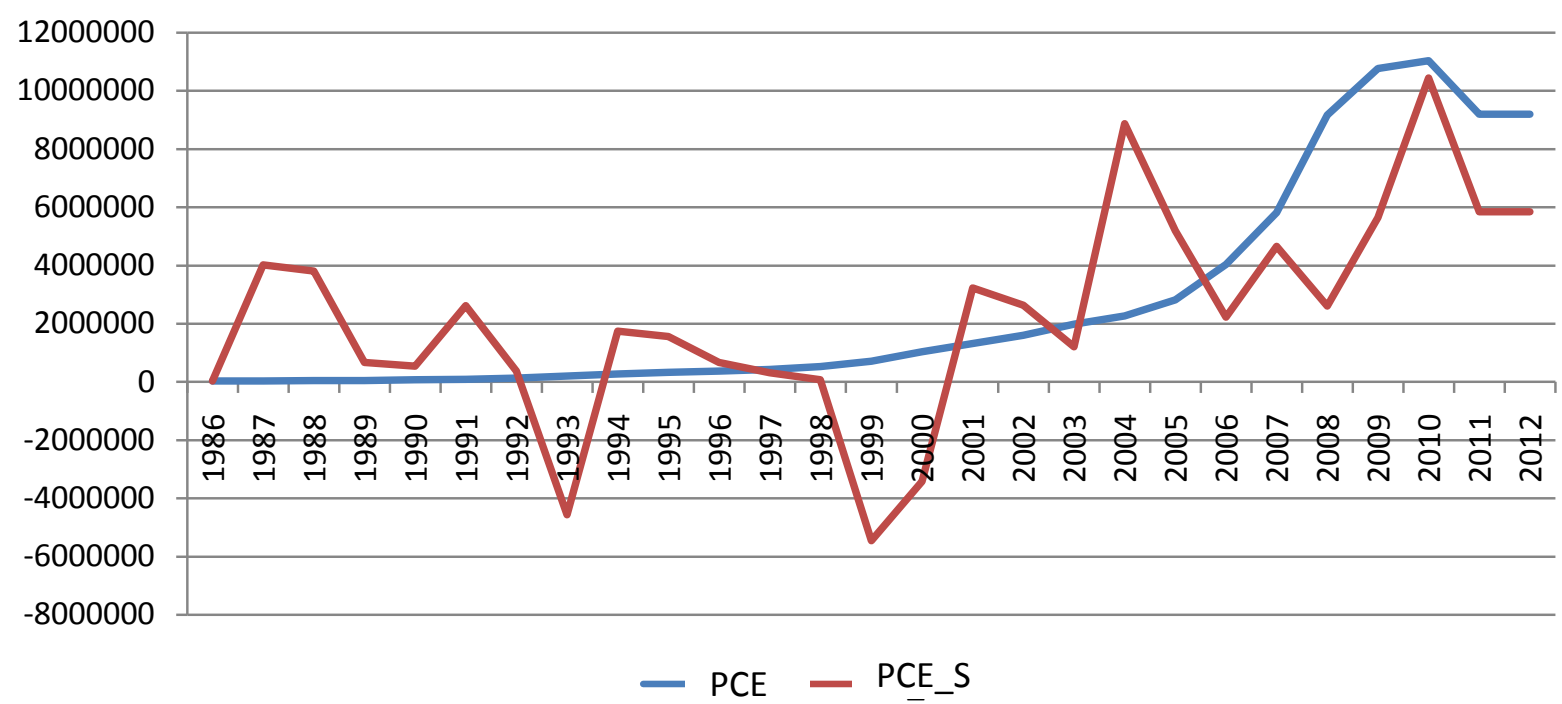


Submit or recommend next manuscript to SCIRP and we will provide best service for you:

Accepting pre-submission inquiries through Email, Facebook, LinkedIn, Twitter, etc. A wide selection of journals (inclusive of 9 subjects, more than 200 journals)

Providing 24-hour high-quality service

User-friendly online submission system

Fair and swift peer-review system

Efficient typesetting and proofreading procedure

Display of the result of downloads and visits, as well as the number of cited articles Maximum dissemination of your research work

Submit your manuscript at: http://papersubmission.scirp.org/

Or contact ojbm@scirp.org 